Article

\title{
The Welfare State as Universal Social Security: A Global Analysis
}

\author{
Kerem Gabriel Öktem \\ Faculty of Sociology, Bielefeld University, 33615 Bielefeld, Germany; E-Mail: kerem.oektem@uni-bielefeld.de
}

Submitted: 30 September 2019 | Accepted: 10 February 2020 | Published: 18 March 2020

\begin{abstract}
Over the past decades, the geography of comparative welfare state research has transformed. Whereas scholars used to focus on a limited number of advanced industrialised democracies, they now increasingly study developments in Europe's periphery, East Asia, and Latin America. So, does this mean that the welfare state has spread around the world? To answer this question, we analyse different ways to measure welfare states and map their results. With the help of International Labour Organization and International Monetary Fund data, we explore measurements based on social expenditures, social rights, and social security legislations and show that each of them faces serious limitations in a global analysis of welfare states. For some measurements, we simply lack global data. For others, we risk misclassifying the extent and quality of some social protection systems. Finally, we present a measurement that is grounded in the idea that the welfare state is essentially about universalism. Relying on a conceptualisation of the welfare state as collective responsibility for the wellbeing of the entire population, we use universal social security as a yardstick. We measure this conceptualization through health and pension coverage and show that a growing number of countries have become welfare states by this definition. Yet, it is possible that at least some of these cases offer only basic levels of protection, we caution.
\end{abstract}

\section{Keywords}

social protection; social rights; universal social security; universalism; welfare effort; welfare state

\section{Issue}

This article is part of the issue “'Universalism' or 'Universalisms' in Social Policies?” edited by Monica Budowski (University of Fribourg, Switzerland) and Daniel Künzler (University of Fribourg, Switzerland).

(C) 2020 by the author; licensee Cogitatio (Lisbon, Portugal). This article is licensed under a Creative Commons Attribution 4.0 International License (CC BY).

\section{Introduction}

Over the past decades, the "geography of comparative welfare state research" (Hort, 2005) has transformed. In previous decades, scholars used to focus only on "eighteen to twenty rich capitalist countries" in the OECD area (Esping-Andersen, 1994, p. 713). Scholars assumed that the very concept of the welfare state could "hardly be stretched" (Esping-Andersen, 1994, p. 713) beyond these countries. Nowadays, research increasingly takes into account developments in Europe's periphery, East Asia, and Latin America (Haggard \& Kaufman, 2008; Huber \& Stephens, 2012; Wood \& Gough, 2006) - even if they still tend to shy away from comparing old and new cases. Collectively, these cases have been labelled "emerging" welfare states (Huber \& Niedzwiecki, 2015). So, does this mean that the welfare state-which is widely perceived as a "European invention" (Gough \& Therborn, 2010)has spread around the world?
In this article, we aim to answer this question. This is trickier than it might appear. The question "when is a state a welfare state" (Esping-Andersen, 1990, p. 18) is rarely explicitly answered in principle, let alone measured in practice. Furthermore, the "dependent variable problem" (Green-Pedersen, 2007) debate has shown that the welfare state is very much a contested concept that encapsulates diverse understandings. This naturally leads to conflicting findings, particularly when it comes to the issue of welfare state change.

In this article, we analyse different ways to conceptualise and measure welfare states and map their results. We explore how different understandings are related to different approaches to measure welfare states. We show that these approaches, based on social expenditures, social rights, and social security legislations, all face serious limitations when applied in a global analyses of welfare states. In some cases, we simply lack data on a global level. In others, we risk misclassifying social 
protection systems. As an alternative, we present a different conceptualisation based on the principle of universalism. Surveying various welfare state definitions, we argue that the hallmark of the welfare state is the assumption of "collective responsibility for the well-being of the entire population" (Kaufmann, 2013, p. 35). We interpret universalism in a minimalist way as requiring universal social security, i.e., the provision of social security to the whole population. This, in turn, is measured through coverage indicators which have long been employed in welfare state research (Flora \& Alber, 1981). This focus on universal social security as a yardstick for welfare stateness resonates well with the recent global emphasis on "leaving no one behind" in the Sustainable Development Goals (International Labour Organization [ILO], 2017).

Our results show how a growing number of countries, including a number of middle-income countries, have defied fears of a "race to the bottom" triggered by globalisation (Rudra, 2008) and universalised social security. However, we caution that the increasing global attention on universal coverage since the 2000s has facilitated the creation of minimal welfare states. These states provide universal coverage for key social risks, but provide protection only on a basic level. This means that these states follow a model of "residual universalism" (Leisering, 2019, p. 358). In such systems, public benefits essentially cater to the poor, while the better-off prefer private benefits. As a result, these systems do not ameliorate but produce new inequalities (Esping-Andersen, 1990, p. 25), which makes their status as universal systems questionable. In case such systems proliferate, using our measurement to map welfare states around the world would become questionable. Instead, more demanding concepts of universalism that take into account benefit levels, as well as the design of the social security system (Leisering, 2019; Martinez Franzoni \& Sánchez-Ancochea, 2016), would have to be employed.

For the analysis, the article mainly draws on data from the ILO and the International Monetary Fund (IMF). ILO data obtained from the ILOSTAT database and from flagship reports is used to analyse social security legislation, social rights, and social security coverage (ILO, 2010, 2017, 2019). IMF data from the Government Finance Statistics (GFS) database is used to analyse social expenditures (IMF, 2019). We complement this data with information from "Social Security Programs Throughout the World," which is gathered by the Social Security Administration and the International Social Security Association, and with country-specific sources (Social Security Administration, 2019).

The article is structured as follows. We start with a discussion of three different welfare state conceptualisations. In the third section, we explore global measurements of welfare states based on these conceptualisations. In the fourth section, we present an alternative conceptualisation of the welfare state based on universal social security. We develop an operationalisation and measurement based on this conceptualisation to map welfare states around the world. In the concluding section, we discuss the strengths and weaknesses of the different measurements and discuss the implications of our findings.

\section{Contrasting Conceptualisations of the Welfare State}

\subsection{The Welfare State as an Ensemble of Policies}

One simple but also popular conceptualisation of the welfare state understands it as a sum of all social policy. For instance, Clasen and Siegel $(2007$, p. 6) conceptualise the welfare state as "all mechanisms which provide social protection against and redistribution of market mechanisms and outcomes." This approach is straightforward and sees the welfare state as an ensemble of policies. The welfare state refers to "sectors of state activity" and is "something that a state has" (Wincott, 2001, p. 413). This conceptualisation is only weakly related to the spread of the notion and the degree of universalism, as the specific content of social policies is left undefined.

In terms of operationalisation and measurement, this understanding of the welfare state corresponds to the measurement of whether countries have adapted certain social security programmes. In this tradition, researchers simply check whether countries have statutory programmes in key branches of social security. These branches are: old age, work injury, unemployment, and sickness (some add family allowances). A welfare state is said to be consolidated when legislation in two (Hort \& Kuhnle, 2000; Pierson, 2004) or three (Hicks, 1999, p. 67) of these branches exist. The ILO (2017) classifies social security systems with a similar measurement. Here, maternity, disability, and survivors insurances are added to the list and countries are classified as having systems with a "comprehensive scope," if programmes in all eight branches exist (ILO, 2017).

This approach faces at least two problems. First, it links the welfare state closely to an ILO model of social security. This model focuses on state provision of cash benefits for clearly delimitated social risks. These risks are related to the normal life course in post-agrarian societies. "Social policy by other means" (Seelkopf \& Starke, 2019), i.e., unconventional policy instruments that serve as functional equivalents of conventional welfare state policies, does not feature at all. Hence, countries with elaborate, but unconventional social security systems might not score high. Researchers argue that there is an affinity between low state capacity, high informality, and unconventional social policy (Seelkopf \& Starke, 2019). Therefore, they likely play a bigger role in the Global South-although they are also found in the Global North. To provide just one example, India's Public Distribution System, which provides subsidised food, has been described as the "centerpiece of India's social protection system" (Bhattacharya, Falcao, \& Puri, 2017).

Second, the approach assumes that having legislation is in itself meaningful. In a global analysis this makes 
limited sense. In the Global South, legislation is frequently not properly implemented and its reach is limited. Yet, with this approach, states that provide social security only on paper might still be perceived as welfare states. For instance, Vietnam and Uzbekistan appear to have legislations in all branches of social security, but few would describe them as welfare states. Hence, in a global analysis, focusing only on the presence of social legislation is problematic.

\subsection{The Welfare State as Welfare Effort}

Arguably the most widely employed concept to measure the welfare state is "welfare effort" (Wilensky, 1975). This refers to the amount of expenditures that a state devotes to social functions, such as health or pensions. The most common operationalisation of welfare effort is public social expenditure as a share of national income, which was the leading indicator in the early era of comparative research (Zöllner, 1963). In this tradition, countries that devote significant shares of their national income to social transfers are-albeit often only implicitly-defined as welfare states (Rudra, 2008, p. 23). Yet, in the literature there is no clear threshold in terms of an amount of social expenditure beyond which countries would be classified as welfare states.

An alternative conceptualisation based on social expenditure has been put forward by Therborn (1984, pp. 31-35). His definition boils down to the idea that welfare states are states that devote more than half of all government expenditures to social policy. In this conceptualisation, the welfare state refers to a "distinct ontology or form of the state" (Wincott, 2001, p. 413). Underlying this conceptualisation is the belief that the priorities of the state are reflected in its budget. A state that spends most of its money on welfare policies is therefore by definition a welfare state. While Therborn's (1984) definition is intriguing, it has not been widely employed by researchers. Furthermore, it has been criticised for its counterintuitive empirical results (Castles, 2006; Esping-Andersen, 1990, p. 20).

Social spending data is "easily available in published sources" (Korpi, 1989, p. 310). Yet, it rarely reflects underlying welfare state conceptualisations. Wilensky (1975, pp. 1-2), for instance, defined the "essence of the welfare state" as "government-protected minimum standards of income, nutrition, health, housing, and education, assured to every citizen as a political right." He justified focusing on welfare effort by stating that it "comes closest to capturing the idea of the welfare state" (Wilensky, 1975, pp. 1-2). The mismatch between conceptualisation and measurement is obvious. It is impossible to understand whether "government-protected minimum standards" are "assured to every citizen as a political right" based on expenditure data (Wilensky, 1975, pp. 1-2). Unsurprisingly, critics argued that "expenditure levels have only indirect bearing on...the core of the modern welfare state" (Korpi, 1989, p. 310) and that they are "epiphenomenal to the theoretical substance of welfare states" (Esping-Andersen, 1990, p. 19). Similarly, spending levels are not directly related to universalism. The amount of overall spending simply does not specify whether the whole population benefits from the social security systems.

In a global comparison of welfare effort, two further issues have to be noted. First, expenditures are partly determined by socio-demographic factors. For instance, the proportion of the aged in a country is closely correlated with social spending. The higher the proportion of the elderly, the higher social expenditures are. Hence, countries with a relatively young population would rarely post high welfare effort even if they provide generous social protection. Accordingly, the analysis would be potentially biased against countries at early stages of the demographic transition. While this issue could be tackled through the control of socio-demographic factors, a second problem is more difficult to overcome. Social spending datasets usually measure gross expenditures. Thus, the way tax systems affect social spending is often disregarded (Adema \& Fron, 2019), making it difficult to compare countries.

\subsection{The Welfare State as Social Rights of Citizenship}

Building on T. H. Marshall's notions of social rights and social citizenship, some scholars developed measurements that would better reflect their underlying welfare state conceptualisation (Stephens, 2010). For them, the welfare state was "a state-organized, institutionalised system of social guarantees" (Esping-Andersen, 1994, p. 714). They developed new indicators to capture the "extent and quality of the social rights that constitute social citizenship" (Korpi, 1989, p. 310). These indicators were collected in the Social Citizenship Indicator Programme (SCIP), a database that "focused on citizens' rights and duties legislated in programmes to alleviate economic needs characterising the human condition" (Korpi \& Palme, 2008, p. 2). The "reference point" for these indicators was "a worker in manufacturing or the metal industry," who has been in continuous employment for the past years (Korpi \& Palme, 2008, p. 4).

In the Marshallian conceptualisation of the welfare state, universality played a key role. The very term social citizenship entails a universalist dimension, in that it is assumed that citizenship applies to all citizens of a country. Furthermore, Marshall (1950, p. 47) speaks of a "universal right to real income." Measurements based on this approach contained universality as one dimension, capturing it through coverage indicators (Esping-Andersen, 1990, p. 70; Korpi, 1989, p. 315). Yet, universality was not conceived as a pre-condition of welfare states in these social rights-based measurements.

Social rights data was popularised by EspingAndersen's Decommodification Index (DI). He understood social rights "in terms of their capacity for 'de-commodification"' (Esping-Andersen, 1990, p. 3). 
Therefore, the index aimed to capture the decommodification of labour, "the degree to which individuals, or families, can uphold a socially acceptable standard of living independently of market" (Esping-Andersen, 1990, p. 37). This was operationalised in three distinct dimensions-access to benefits, income replacement, and the range of entitlements - and measured for three programmes-unemployment insurance, sick pay, and old-age pensions. While the index was devised to measure decommodification-and also Scruggs' Benefit Generosity Index (BGI) that was modelled after the DI (Scruggs \& Allan, 2006)-it has been widely used as a proxy for the welfare state.

Both social rights indexes have been computed for classic welfare states. However, it remains unclear how valid a global application of these indexes would be. The concept of decommodification presupposes that a prior commodification of labour has taken place. This means that employment mainly occurs in formal labour markets, which is not necessarily the case in the Global South. In many southern countries, large sections of the labour force remain involved in subsistence agriculture. Thus, wage labour exists alongside other means of livelihood (Böger \& Öktem, 2019; Rudra, 2008; Wood \& Gough, 2006). Moreover, the indexes measure three social insurance programmes as it was believed that these "form a key part of modern welfare states and of what Thomas H. Marshall termed social citizenship" (Korpi \& Palme, 2008, p. 2). Other policy areas, such as healthcare, are not captured (Bambra, 2005). This is curious, as Marshall (1950) himself saw health as crucial for social citizenship. Finally, due to the focus on cash benefits provided primarily through certain social insurance programmes, the indexes would likely overlook "functional equivalents" (Bonoli, 2007) of conventional programmes. For instance, in the realm of unemployment, severance pay and employment-guarantee schemes are two functional equivalents that would not be captured by social rights indexes. Countries that employ these policies would thus be underestimated by such indexes. There is reason to believe that such functional equivalents are more prevalent in the Global South. Comparative research reports an "inverse relation between income level of a country and severance pay generosity" (Holzmann, Pouget, Vodopivec, \& Weber, 2011, p. 21). Employment-guarantee schemes, which link public works with cash benefits, are found in some crucial southern countries such as India and Ethiopia (ILO, 2017). Perhaps this is one reason why social rights indexes have not been generated beyond a limited number of countries in the Global North.

\section{Mapping Welfare States around the World}

\subsection{Measuring Welfare States through Social Security Legislation}

Measuring welfare states through the existence of social security legislation is a simple but effective way to grasp how the welfare state has spread around the world. Today, "even the poorest Third World nation has some form of social policy" (Esping-Andersen, 1994, p. 713). Therefore, legislation can be expected to be a dimension that can be employed in a global analysis of welfare states. The ILO provides in-depth data on whether statutory legislation exists in eight branches of social security. The higher the number of branches with legislation, the more comprehensive a country's social security system is. Previous research has set two or three legislations in the key four or five branches as a threshold for "welfare state consolidation" (Hicks, 1999; Hort \& Kuhnle, 2000; Pierson, 2004).

Our results for 181 countries and territories (see Supplementary File) show that social security legislation has truly spread throughout the world. 148 countries have legislation that provides cash benefits against more than half of the eight social risks. The countries with less comprehensive legislation are mainly found in subSaharan Africa. Only a handful of countries do not have at least two programmes in the classic four branches (old age, unemployment, sickness, and work injury). By the standards of previous research, most countries in the world are consolidated welfare states, and 70 countries even have programmes in all eight branches, thus being classified as "comprehensive" social security systems by the ILO (2017). Overall, the "world has seen social protection systems develop at an impressive pace" (ILO, 2017, p. 4)-and this development continues at full speed (Grünewald \& Seelkopf, 2016). Still, the results also suggest that simply measuring whether a statutory nationwide programme exists is insufficient to differentiate between welfare states and non-welfare states.

\subsection{Measuring Welfare States through Public Social Expenditure}

On a global level, data on public social expenditure remains surprisingly fragmentary. The most widely used cross-national databases feature high income countries, therefore excluding the majority of countries. The ILO's Cost of Social Security series, which had a global approach and served as the basis for pioneering comparative studies (Wilensky, 1975; Zöllner, 1963), ceased to be updated in the 1990s. While the ILO's World Social Protection Reports contain data on social expenditure, they only compile data from other sources, such as Eurostat, which puts doubt on the coherence of the data.

Currently, the IMF's GFS is the best available data for a global analysis of social expenditure. GFS contains spending data based on classification of government functions. To gauge welfare effort researchers have combined social protection and health data. Yet, we also report education and housing data, as these categories are sometimes also perceived as part of the welfare state (Therborn, 1984). GFS provides data for different levels of government, such as central, local, or general government. So far, research has focused on central govern- 
ment expenditures (Grünewald \& Seelkopf, 2016, p. 120; Rudra, 2008, p. 27). However, social policy is not always the responsibility of the central government. In many states, social policy is partly left to the local government level. Hence, central government expenditures are weakly correlated to general government expenditures. To quote just one example, based on budgetary central government data, China spent $0.25 \%$ on social protection and health in 2016-the corresponding general government figure is $10 \%$. This shows that central government data is not necessarily a good proxy for overall welfare effort of a state. Therefore, we use general government data for our analysis. Unfortunately, data for general government expenditures is limited to around 60 countries. In order to broaden the reach of our analysis, we also report results for countries with relatively high spending on lower levels of government. In this way, we are able to include 74 countries and territories in the analysis. Unfortunately, most of these countries are either OECD or post-communist countries and thus the global reach of the analysis remains limited.

The data (see Supplementary File) shows that most countries post a relatively high welfare effort: 49 of 65 cases have social expenditures in excess of $10 \%$ of GDP. Moreover, if we include housing and education, 57 of 74 countries spend more than half of their budget on social expenditures. In that sense, they fulfil Therborn's (1984) definition of a welfare state. Denmark even devotes $73 \%$ of its budget to social policy. These high levels of welfare effort are mainly due to the large number of OECD, EU, and post-communist countries, which have historically high social spending. For instance, average social spending is $21.9 \%$ in OECD countries, while it is only $10.3 \%$ in non-OECD countries. The lowest welfare effort is observed in Myanmar, which spends only 2\% of GDP on social protection and health. Among the countries from the Global South, Mauritius, China, and Egypt stand out with relatively high social spending and a high share of social spending. Additionally, Argentina, Brazil, Chile, Costa Rica, and the Marshall Islands, for which we have only partial data, also post high social spending and likely to devote more than half of their budget to social policy. Despite limited data, we can thus conclude that at least some countries in the Global South gradually approach OECD standards of welfare effort.

\subsection{Measuring Welfare States through Social Rights}

Comparative researchers appear to have reached a "silent agreement" that welfare states are best captured through social rights (Kühner, 2015), even if concerns about "convergent validity" have been voiced (Bolukbasi \& Öktem, 2018; Wenzelburger, Zohlnhöfer, \& Wolf, 2013). Accordingly, social rights indexes have been widely used as proxies for the welfare state. The two popular social rights datasets, the SCIP and the Comparative Welfare Entitlements Dataset (CWED), however, focus on the Global North. Recent geographical expansions notwithstanding, the datasets still include only around 30 (mostly European) countries. Due to the lack of data, the leading social rights indexes, Esping-Andersen's DI (which is based on SCIP) and Scruggs' BGI (which is based on (WED), cannot be computed on a global level. Still, the mathematical structure of the indexes makes it possible to estimate-with limited data-potential maximum scores that countries can achieve. These scores should not be seen as an assessment of the quality of the respective social protection system, however. Rather, they indicate the likelihood that the respective country has developed a social security system which is roughly comparable to those of classic welfare states. Moreover, the scores give an indication of which countries certainly lack such a social security system.

Although it is possible to compute potential maximum levels for both indexes, we focus here on the DI, because it has a simpler structure than the BGI. The DI is the sum of three sub-indexes for unemployment insurance, sick pay, and old-age pensions. For unemployment insurance and for sick pay, replacement rates, waiting days, the qualification period, and benefit duration are measured; for old-age pensions the minimum and standard replacement rates, the share of employee contributions in pension funding, and the qualification period are measured. These indicators are standardised in a peculiar manner. A country is assigned a score of 2 if it posts a value within one standard deviation (SD) of the indicator's mean. It is assigned a score of 3 if it posts a value greater than one SD above the mean. It is assigned a score of 1 if it posts a value lower than one SD below the mean. Replacement rates are given double weight as they are assumed to be more important. To compute sub-index scores, the values for each indicator are summed up and multiplied by the coverage level of the programme.

The maximum score for the full DI is 48 . This score is achieved if coverage is universal in all programmes and all scores for the remaining indicator are more than one SD above the mean. The DI scores crucially depend on coverage, as the sum of all indicators in a branch is multiplied by coverage to signify the "probability that any given person will possess the right" to benefit (Esping-Andersen, 1990, p. 49). With information on whether a country has legislation in the respective branch of social security and an estimate of programme coverage, one can significantly narrow the range of values that the index can take. Assuming that programmes exist in all three branches, the maximum score is three times the minimum score. For instance, assuming that legislation in all three branches exists, a country with full coverage in all three branches would range between 16 and 48. If legislation only exists for old-age pensions, but not for unemployment insurance and sick pay, as in many African countries, a country could reach at best a score of 16 .

Data on whether statutory programmes exist and on pension coverage can be retrieved from the ILO. However, for unemployment and sick pay coverage data 
is not easily available. Looking at SCIP data (for the Global North) for the number of people insured in different programmes, we find that the data for pensions, unemployment, and sickness do not vary randomly. Rather, in the overwhelming number of cases, the number of people insured for pension (active coverage) is either equal to or exceeds the number of people insured against unemployment and sickness. In light of this fact, we can assume that unemployment and sick pay coverage will rarely be higher than pension coverage. In this sense, we can use the pension coverage data to estimate the potential maximum level that unemployment and sick pay coverage might take. To provide an example, ILO data indicates that $41 \%$ of the labour force contributes to pensions in Algeria (ILO, 2017). Yet, we do not know what share of the labour force is insured against unemployment and sickness. Now, to estimate potential maximum decommodification levels, we assume that unemployment and sick pay coverage is, at best, $41 \%$. Assuming that the respective country achieves the highest possible scores on the remaining indicators, we arrive at an estimate for the potential maximum level that a country could score. As explained above, this does not signify real DI scores.

Based on these considerations, we construct potential DI scores for 165 countries and territories (see Supplementary File). Unsurprisingly, nearly the whole Global North posts high scores, with the United States being the welfare laggard among the northern countries. Interestingly, a number of post-communist countries, such as Kazakhstan, Mongolia, and Russia stand out as having potentially high decommodification. Additionally, China, Taiwan, and Hong Kong also post high values. Within Latin America, Uruguay, Chile, and Argentina score well. In sub-Saharan Africa, South Africa has by far the highest score. Whether these countries really provide high levels of social rights remains open, however. If, for instance, replacement rates in these countries are low, or unemployment and sick pay coverage are far below pension coverage, DI scores would be markedly below our estimates for potential decommodification.

Around 70 countries have low potential DI scores. These countries are mostly from sub-Saharan Africa, South and Southeast Asia. Moreover, some Middle Eastern countries, such as Saudi Arabia or Oman, also score low. Interestingly, two countries that have been listed among the "most advanced welfare states in the Global South" (Huber \& Niedzwiecki, 2015, p. 796), South Korea and Costa Rica, feature unimpressive scores. Similarly, Mauritius, which has been applauded for its universal social protection system (Sandbrook, Edelman, Heller, \& Teichman, 2007) is also not performing too well. If real DI scores were to be computed for these countries, it is likely that they would be significantly below our expectations. These examples point to the problem that the DI is modelled after a certain type of social security system. This makes it arguably ill-suited to assess countries where functional equivalents of conventional welfare state policies prevail.

\section{The Welfare State as Universal Social Security}

In this section, we develop a simple measurement that is devised to capture whether a country has become a welfare state (Öktem, 2016). The measurement is grounded in the assumption that a key characteristic of the welfare state is universalism. Universalism is a crucial concept in welfare state research, but one which is also very much contested. Yet, there is "a reasonable degree of unanimity" that at minimum, it requires that the entire population must be included by social policy and have access to benefits (Anttonen \& Sipilä, 2012, p. 37). In other words: There must be universal social security. This, we argue, is the lowest common denominator of most of those conceptualisations that perceive the welfare state to be something a state is-and not what it does (Wincott, 2001, p. 413).

As we have seen, there are various welfare state conceptualisations. However, most of them have a common feature. They share the assumption that in order to qualify as a welfare state, a country has to ensure universal social protection of its population. Let us take Wilensky's (1975) definition as an example. In his view, the "essence of the welfare state is government-protected minimum standards assured to every citizen as a political right, not as charity" (Wilensky, 1975, p. 1). Providing these "minimum standards" to every citizen essentially means ensuring universal social protection. Taking this definition seriously, a state has to guarantee these "minimum standards" to be a welfare state.

This emphasis on guaranteeing a 'minimum' is also found in the British welfare state tradition (Veit-Wilson, 2000). Other approaches go beyond a minimum. EspingAndersen, for instance, focuses on adequacy. As we have seen, universality is an important component of his DI because of the coverage indicators. He defines the welfare state in more general terms as "a state-organised, institutionalised system of social guarantees that, unconditionally, assures adequate living standards to all citizens" (Esping-Andersen, 1994, p. 714). These "social guarantees" are essentially rights-based social security policies that, again, have to apply to "all citizens," i.e., universal social security.

An alternative way to conceptualise the welfare state has concentrated on redistribution. The best-known example is Briggs' (1961, p. 228) definition that focuses on how politics modifies "the play of market forces." Yet, key components of Briggs' (1961) definition are social security ("narrowing the extent of insecurity") and universalism ("all citizens without distinction of status or class"). Here, universal social security is a means by which the state ensures redistribution.

Whereas these conceptualisations focus on specific outcomes, others remain more abstract. Kaufmann (2013, p. 35), for instance, argues that "the specific difference that defines welfare state developments," as opposed to social policy developments in general, is the assumption of "collective responsibility for the well-being 
of the entire population mediated by political action." This "collective responsibility" has to be expressed not just in "normative orientations" (Leisering, 2003), but also in social policy. While in Kaufmann's understanding the precise policies would depend on the national context, social security policies would, in any case, be part of the policy mix. Given that the focus is on the inclusion of the "entire population," this approach thus also requires universal social security.

These diverse understandings of the welfare state all agree that a state has to ensure universal social security to be a welfare state. Hence, universalism, in its "minimalist definition" (Martinez Franzoni \& SánchezAncochea, 2016, pp. 28-30), can be described as a key characteristic of welfare states-it is "the idea or principle that makes a state a welfare state" (Anttonen, Häikiö, \& Stefánsson, 2012, p. 191). It seems that whatever else one expects from the welfare state-be it redistribution (Briggs, 1961), institutionalisation of social protection (Alber, 1989, p. 30), or full employment (Mishra, 1984, p. xi)-one also expects that a welfare state assumes responsibility for the social protection of the entire population. In light of this finding, I conceptualise the welfare state as a state, whose citizens are all protected by the formal social security system.

This conceptualisation excludes informal or traditional social security arrangements, i.e., family or community-based social protection mechanisms. These mechanisms, such as rotating savings and credit association, traditionally play an important role across the Global South (Ahmad, 1991; Wood \& Gough, 2006). Yet, insofar as they are neither state-provided nor regulated by the state, they should be seen as alternatives to the welfare state. At the same time, the conceptualisation does not determine through which particular policies the population is protected. This aspect is important for a global analysis because it allows for the inclusion of unconventional welfare states that defy a policy model. Still, it concentrates on the social security system as the defining area of the welfare state. Furthermore, the definition does not assume state-provided welfare, but leaves open the possibility that the state achieves universal social protection by means of regulation. In this sense, it includes "regulatory" in addition to "provider" welfare states (Leisering, 2011; Levi-Faur, 2014).

Although our approach sees universalism at the heart of the welfare state, it is important to note that it does not presuppose "programme universalism" (Leisering, 2019 , p. 399). This term refers to the idea that in each branch of social security, the population is covered by a single programme and thus has access to similar services and benefits. Instead, countries with "systemic universalism," which provide different programmes for different parts of the population in each branch of social security, are also included in this conceptualisation (Leisering, 2019 , p. 405). Systemic universalism is found, for instance, in continental European Bismarckian pension systems. In these countries, different occupational groups have separate programmes, yet (nearly) the whole population is covered. Hence, what matters is that collectively programmes cover the whole population.

So, how can we capture whether states ensure universal social security, i.e., operationalise the definition? Welfare state research has classically focused on four areas of social security that correspond to four social risks: old age, sickness, unemployment, and work injury. Yet, one can make a case for excluding the latter two in a global measurement of welfare states. Protection against work injuries has not received much attention from comparative researchers. Even when included in measurements of the welfare state, it was given less weight than other branches of social security (Flora \& Alber, 1981, p. 54). Measuring protection against unemployment is difficult due to the prevalence of functional equivalents of unemployment insurance, which are hard to measure consistently. Furthermore, as a social risk, unemployment appears to be less pressing in some societies than in others. For instance, in communist countries the existence of a "right" and "obligation to work" meant that policymakers did not see any need to introduce unemployment insurance (Kaufmann, 2013). Old age and sickness, on the other hand, could be more aptly described as universal social risks. They are part of the human condition and not simply the by-product of a particular economic system. Moreover, they are by far the most important branches of social security in terms of expenditure. Therefore, we operationalise universal social security as universal protection against old age and sickness.

Hence, we understand the welfare state as a state, which ensures universal protection against old age and sickness. We measure universal protection against sickness through health coverage. Here, we mainly rely on data from the ILO, which measures legal health coverage through the number of "affiliated members of health insurance" in the case of insurance-based systems and the number of people "having free access to health care services provided by the State" in the case of national health systems (ILO, 2017, p. 375). Admittedly, legal coverage is not a perfect measure for understanding whether people have effective access to health services. It only captures "entitlement universalism," not "receipt universalism" (Leisering, 2019). Yet, so far, we lack a better measurement on the global level. For protection against oldage, we measure "old-age effective coverage" (ILO, 2017, p. 361). We rely on data from the ILO and other sources that estimate the proportion of people above the legal retirement age that receives old age pensions. This approach offers two advantages over the traditional way of measuring pension coverage through the number of active contributors (Flora \& Alber, 1981). First, for various reasons, in many countries legal entitlement is not sufficient for claiming benefits. Second, in many countries a sizeable share of the elderly receives non-contributory pensions (Böger, 2013). In these countries, counting the number of active contributors to a pension system would underestimate coverage. 
For measuring whether countries are welfare states, we combine health coverage and pension coverage with a logical conjunction. Therefore, the universality of social security is defined by the lower of the two scores. This reflects the assumption that both health and pensions are equally necessary components of the concept of social security. Health reflects the care dimension, whereas pension reflects the cash dimension of social security. A universal programme in one branch cannot make up for a lack of universality in the other. Social security is a package, which at its minimum contains protection against the two most universal social risks, illness and old age. For universal social security, people have to be covered in both dimensions.

Our measurement of the welfare state as universal social security includes 160 countries and territories (see Supplementary File). Our results show that 39 cases have coverage levels of at least $90 \%$ and can thus be reasonably described as welfare states. These countries also post high social expenditures, spending on average $20.6 \%$ of their GDP on social protection and health. Most of these countries are EU or OECD members or post-communist countries. The exceptions are Mauritius, South Africa, and China. Another 26 "protowelfare states" (Wood \& Gough, 2006) cover at least two thirds of the population. These include five Latin American and a number of post-communist countries. Furthermore, Greece and the United States are also in this group. On average, these countries spend $14.2 \%$ of their GDP on social policy.

From our data, 22 countries cover between one and two thirds of the population. For these countries it remains unclear whether they can be perceived as welfare states. This is a heterogeneous group, with several cases from the Middle East. 33 countries cover less than one third, and another 40 countries cover less than $10 \%$. By our definition, these would be non-welfare states. This group includes many cases from Africa and South Asia. Furthermore, for another 28 countries we lack data in one dimension. 13 of these cases score low on the remaining dimension, so they can also be described as nonwelfare states. Overall, the results reveal that the core idea behind the welfare state- universal social securityhas spread beyond Europe, albeit to a limited degree. Interestingly, there is a decent correlation between universal social security and social spending $(r=0.61)$.

\section{Conclusion}

In this article, we explored whether the welfare state-a European invention-has spread around the world. For this purpose, we analysed three popular understandings of the welfare state and their associated measurements. These measurements based on social legislation, social expenditures, and on social rights of citizenship revealed shortcomings that make them ill-suited for a global analysis of welfare states. Mapping welfare states through social security legislation is prone to overestimate social security in countries where legislation is not effectively implemented. At the same time, it is prone to miss out on unconventional welfare states that rely on social policy by other means. Mapping welfare states through expenditures is difficult on a global level due to data limitations. Furthermore, welfare effort is linked not just to the quality of social protection, but also to the sociodemographic profile of the country, making global comparisons demanding. Mapping welfare states through social citizenship is also difficult due to data limitations. Even if data were available on a global level, however, the results would not necessarily be a good proxy for the welfare state because of the close link to a particular policy model. Functional equivalents of conventional policies would be overlooked.

As an alternative, we proposed to conceptualise the welfare state through universalism, which we interpreted as universal social security. This is the lowest common denominator of influential welfare state definitions. We operationalised this concept as universal protection against old age and sickness and measured it through health and pension coverage. This proved to be a simple but effective way to undertake a global analysis of welfare states. It revealed that an increasing number of countries have universalised social security, i.e., have become welfare states. This overall conclusion is supported by the results of the three more common measurements of the welfare state, even if the scores for single countries vary.

While fruitful, our approach also has shortcomings. First, the measurement does not take into account social policy by other means. However, given that it only captures two very basic branches of social security, the problem should be less severe than for some other measurements, such as the DI. Second, since the 2000s, the global social policy discourse focused on the fact that a minority received generous social protection while the majority remained excluded. In response, international organisations pushed for "extending social security to the excluded" (Leisering, 2009). In some cases, this meant universal coverage on a low level. In healthcare, some countries such as China built virtually universal health insurances, which cover only part of the treatment expenses. In pensions, social pensions with benefit levels too low to lift recipients out of poverty have spread (Böger, 2013). Such systems may provide universal coverage, but they hardly offer social security. These systems are good examples of "residual universalism" (Leisering, 2019). Although universal in terms of coverage, these systems essentially focus on the poor and offer low quality benefits and services. As a result, such systems facilitate the expansion of market-based options for the middle classes. This, in turn, would lead to the rise of new inequalities between those who have to rely on public programmes and those covered by private services. While "residual universalism" clearly constitutes an improvement over having no social security, it does not really correspond to a universalistic understanding of the welfare 
state. If more countries adopt such minimal but universal systems, our measurement of the welfare state would no longer work. In this case, one would need to select a more demanding conceptualisation among the varieties of universalism proposed in the literature. This could entail taking into account benefit levels, benefit distribution, the institutional design of social policies, and the overall architecture of social security systems (Anttonen et al., 2012; Brady \& Bostic, 2015, p. 274; Jacques \& Noël, 2018, pp. 74-75; Korpi \& Palme, 1998; Leisering, 2019, pp. 357-369; Martinez Franzoni \& Sánchez-Ancochea, 2016, pp. 5-8).

So, what implications does this global analysis have for comparative welfare state research? Has the welfare spread around the world? Partly, yes. A number of countries beyond the core cases can be understood as welfare states. This is visible in legislation, spending, and coverage. These cases could be compared to the classic welfare states to reveal new insights. In addition to the post-communist countries-which already had complex social security systems, relatively high social expenditures, and fairly universal coverage before transitioncountries from the Southern Cone of Latin America, as well as China, stand out. Hence, these countries could be integrated into mainstream research. It would be interesting, for instance, to generate social rights data to explore in how far instruments devised to capture northern welfare states also help us make sense of welfare states in the Global South. Beyond these cases, it would be also worthwhile to directly compare seemingly unconventional welfare states, such as Costa Rica and South Africa, with classic welfare states.

\section{Acknowledgments}

The author would like to thank Lutz Leisering, Tolga Bolukbasi, and Tobias Böger for very valuable comments and suggestions on an earlier version of the article.

\section{Conflict of Interests}

The author declares no conflict of interests.

\section{Supplementary Material}

Supplementary material for this article is available online in the format provided by the authors (unedited).

\section{References}

Adema, W., \& Fron, P. (2019). The OECD SOCX manual: 2019 edition. Paris: OECD. Retrieved from http:// www.oecd.org/social/soc/SOCX_Manuel_2019.pdf

Ahmad, E. (Ed.). (1991). Social security in developing countries. Oxford: Oxford University Press.

Alber, J. (1989). Der Sozialstaat in der Bundesrepublik 1950-1983 [The welfare state in West Germany 1950-1983]. Frankfurt am Main: Campus.
Anttonen, A., \& Sipilä, J. (2012). Universalism in the British and Scandinavian social policy debates. In A. Anttonen, L. Häikiö, \& K. Stefánsson (Eds.), Welfare state, universalism and diversity (pp. 16-41). Cheltenham: Edward Elgar.

Anttonen, A., Häikiö, L., \& Stefánsson, K. (2012). The future of the welfare state: Rethinking universalism. In A. Anttonen, L. Häikiö, \& K. Stefánsson (Eds.), Welfare state, universalism and diversity (pp. 187-196). Cheltenham: Edward Elgar.

Bambra, C. (2005). Cash versus services: 'Worlds of welfare' and the decommodification of cash benefits and health care services. Journal of Social Policy, 34(2), 195-213.

Bhattacharya, S., Falcao, V. L., \& Puri, R. (2017). The public distribution system in India: Policy evolution and program delivery trends. In H. Alderman, U. Gentilini, \& R. Yemtsov (Eds.), The 1.5 billion people question: Food, vouchers, or cash transfers? (pp. 43-105). Washington, DC: The World Bank.

Böger, T. (2013). Diffusing social citizenship at the margins? The spread of social pensions in the Global South (Unpublished Master's dissertation). Bielefeld University, Bielefeld, Germany.

Böger, T., \& Öktem, K. G. (2019). Levels or worlds of welfare? Assessing social rights and social stratification in Northern and Southern countries. Social Policy \& Administration, 53(1), 63-77.

Bolukbasi, H. T., \& Öktem, K. G. (2018). Conceptualizing and operationalizing social rights: Towards higher convergent validity in SCIP and CWED. Journal of European Social Policy, 28(1), 86-100.

Bonoli, G. (2007). Too narrow and too wide at once: The 'welfare state' as a dependent variable in policy analysis. In J. Clasen \& N. A. Siegel (Eds.), Investigating welfare state change: The 'dependent variable problem' in comparative analysis (pp. 24-39). Cheltenham: Edward Elgar.

Brady, D., \& Bostic, A. (2015). Paradoxes of social policy: Welfare transfers, relative poverty, and redistribution preferences. American Sociological Review, 80(2), 268-298.

Briggs, A. (1961). The welfare state in historical perspective. European Journal of Sociology, 2(2), 221-258.

Castles, F. G. (2006). The growth of the post-war public expenditure state: Long-term trajectories and recent trends (Working Paper No. 35). Bremen: Collaborative Research Center 597-Transformations of the State.

Clasen, J., \& Siegel, N. A. (2007). Comparative welfare state analysis and the 'dependent variable problem.' In J. Clasen \& N. A. Siegel (Eds.), Investigating welfare state change (pp. 3-12). Cheltenham: Edward Elgar.

Esping-Andersen, G. (1990). The three worlds of welfare capitalism. Cambridge: Polity Press.

Esping-Andersen, G. (1994). Welfare states and the economy. In N. J. Smelser \& R. Swedberg (Eds.), Handbook of economic sociology (pp. 711-732). Princeton, NJ: Russell Sage Foundation. 
Flora, P., \& Alber, J. (1981). Modernization, democratization, and the development of welfare states in Western Europe. In P. Flora \& A. J. Heidenheimer (Eds.), The development of welfare states in Europe and America (pp. 37-80). New Brunswick, NJ: Transaction Books.

Gough, I., \& Therborn, G. (2010). The global future of welfare states. In F. G. Castles, S. Leibfried, J. Lewis, H. Obinger, \& C. Pierson (Eds.), The Oxford handbook of the welfare state (pp. 703-720). Oxford: Oxford University Press.

Green-Pedersen, C. (2007). More than data questions and methodological issues: Theoretical conceptualization and the dependent variable 'problem' in the study of welfare reform. In J. Clasen \& N. A. Siegel (Eds.), Investigating welfare state change (pp. 13-23). Cheltenham: Edward Elgar.

Grünewald, A., \& Seelkopf, L. (2016). Auslaufmodell oder Erfolgsgeschichte? Soziale Sicherung in globaler Perspektive [A thing of the past or success story? Social security in global perspective]. Zeitschrift für Sozialreform, 62(2), 111-140.

Haggard, S., \& Kaufman, R. R. (2008). Development, democracy, and welfare states: Latin America, East Asia, and Eastern Europe. Princeton, NJ: Princeton University Press.

Hicks, A. M. (1999). Social democracy and welfare capitalism. Ithaca, NY: Cornell University Press.

Holzmann, R., Pouget, Y., Vodopivec, M., \& Weber, M. (2011). Severance pay programs around the world: History, rationale, status, and reforms (Discussion Paper No. 5731). Bonn: IZA-Institute of Labor Economics.

Hort, S. E. O. (2005). The geography of comparative welfare state research: A comment. Global Social Policy, 5(1), 14-17.

Hort, S. E. O., \& Kuhnle, S. (2000). The coming of East and South-East Asian welfare states. Journal of European Social Policy, 10(2), 162-184.

Huber, E., \& Niedzwiecki, S. (2015). Emerging welfare states in Latin America and East Asia. In S. Leibfried, E. Huber, M. Lange, J. D. Levy, F. Nullmeier, \& J. D. Stephens (Eds.), The Oxford handbook of transformations of the state (pp. 796-812). Oxford: Oxford University Press.

Huber, E., \& Stephens, J. D. (2012). Democracy and the left: Social policy and inequality in Latin America. Chicago, IL: University of Chicago Press.

International Labour Organization. (2010). World social security report 2010/11: Providing coverage in times of crisis and beyond. Geneva: International Labour Organization.

International Labour Organization. (2017). World social protection report 2017-19. Geneva: International Labour Organization.

International Labour Organization. (2019). Data. International Labour Organization. Retrieved from https:// ilostat.ilo.org/data
International Monetary Fund. (2019). Home. International Monetary Fund. Retrieved from https://data. imf.org

Jacques, O., \& Noël, A. (2018). The case for welfare state universalism, or the lasting relevance of the paradox of redistribution. Journal of European Social Policy, 28(1), 70-85.

Kaufmann, F.-X. (2013). Variations of the welfare state. Berlin: Springer.

Korpi, W. (1989). Power, politics, and state autonomy in the development of social citizenship: Social rights during sickness in eighteen OECD countries since 1930. American Sociological Review, 54(3), 309-328.

Korpi, W., \& Palme, J. (1998). The paradox of redistribution and strategies of equality: Welfare state institutions, inequality, and poverty in the Western countries. American Sociological Review, 63(5), 661-687.

Korpi, W., \& Palme, J. (2008). The social citizenship indicator program (SCIP): General coding comments. Stockholm: Swedish Institute for Social Research.

Kühner, S. (2015). What if we waited a little longer? The dependent variable problem within the comparative analysis of the welfare state revisited. Social Policy Review, 27, 199-224.

Leisering, L. (2003). Nation state and welfare state: An intellectual and political history. Journal of European Social Policy, 13(2), 175-185.

Leisering, L. (2009). Extending social security to the excluded. Global Social Policy, 9(2), 246-272.

Leisering, L. (2011). Transformations of the state: Comparing the new regulatory state to the post-war provider state. In L. Leisering (Ed.), The new regulatory state (pp. 254-274). London: Palgrave Macmillan.

Leisering, L. (2019). The global rise of social cash transfers. Oxford: Oxford University Press.

Levi-Faur, D. (2014). The welfare state: A regulatory perspective. Public Administration, 92(3), 599-614.

Marshall, T. H. (1950). Citizenship and social class and other essays. Cambridge: Cambridge University Press.

Martinez Franzoni, J., \& Sánchez-Ancochea, D. (2016). The quest for universal social policy in the South. Cambridge: Cambridge University Press.

Mishra, R. (1984). The welfare state in crisis: Social thought and social change. New York, NY: St. Martin's Press.

Öktem, K. G. (2016). Pathways to universal social security in lower income countries: Explaining the emergence of welfare states in the developing world (Unpublished Doctoral dissertation). Bilkent University, Ankara, Turkey.

Pierson, C. (2004). 'Late industrializers' and the development of the welfare state. In P. T. Mkandawire (Ed.), Social policy in a development context (pp. 215-245). London: Palgrave Macmillan.

Rudra, N. (2008). Globalization and the race to the bottom in developing countries: Who really gets hurt? Cambridge: Cambridge University Press. 
Sandbrook, R., Edelman, M., Heller, P., \& Teichman, J. (2007). Social democracy in the global periphery. Cambridge: Cambridge University Press.

Scruggs, L., \& Allan, J. (2006). Welfare-state decommodification in 18 OECD countries: A replication and revision. Journal of European Social Policy, 16(1), 55-72.

Seelkopf, L., \& Starke, P. (2019). Social policy by other means: Theorizing unconventional forms of welfare production. Journal of Comparative Policy Analysis, 21(3), 219-234.

Social Security Administration. (2019). Social security programs throughout the world. Social Security Administration. Retrieved from https://www.ssa.gov/ policy/docs/progdesc/ssptw

Stephens, J. D. (2010). The social rights of citizenship. In F. G. Castles, S. Leibfried, J. Lewis, H. Obinger, \& C. Pierson (Eds.), The Oxford handbook of the welfare state (pp. 511-525). Oxford: Oxford University Press.

Therborn, G. (1984). Classes and states welfare state developments, 1881-1981. Studies in Political Economy, 14(1), 7-41.
Veit-Wilson, J. (2000). States of welfare: A conceptual challenge. Social Policy \& Administration, 34(1), 1-25.

Wenzelburger, G., Zohlnhöfer, R., \& Wolf, F. (2013). Implications of dataset choice in comparative welfare state research. Journal of European Public Policy, 20(9), 1229-1250.

Wilensky, H. L. (1975). The welfare state and equality. Berkeley, CA: University of California Press.

Wincott, D. (2001). Reassessing the social foundations of welfare (state) regimes. New Political Economy, 6(3), 409-425.

Wood, G. D., \& Gough, I. (2006). A comparative welfare regime approach to global social policy. World Development, 34(10), 1696-1712.

Zöllner, D. (1963). Öffentliche Sozialleistungen und wirtschaftliche Entwicklung: Ein zeitlicher und internationaler Vergleich [Public social benefits and economic development: A temporal and international comparison]. Berlin: Duncker \& Humblot.

\section{About the Author}

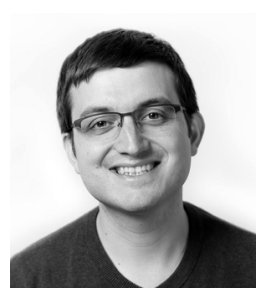

Kerem Gabriel Öktem is a Post-Doctoral Researcher at the Faculty of Sociology of Bielefeld University. He received his PhD from the Department of Political Science at Bilkent University in 2016 for his dissertation on the emergence of welfare states in the Global South. His research focuses on how to conceptualise, measure, and compare social policy in the Global South and the Global North. 